\title{
Differences in the educational paths of entrepreneurs and employees
}

\author{
Uschi Backes-Gellner *, Simone N. Tuor, Daniela Wettstein \\ University of Zurich, Chair for Empirical Research in Business, Industrial Relations \\ and Human Resource Management
}

\begin{abstract}
This paper examines whether individuals who become either entrepreneurs or employees follow systematically different educational paths to a given educational level. Following Lazear's jack-of-all-trades theory, we expect that entrepreneurs aim at a balanced set of different skills - that is, they combine academic and vocational skills - while employees specialize in one skill. This means that entrepreneurs follow educational paths that combine different types of education, while employees follow same-type paths while climbing up the educational ladder. We use the Swiss Labor Force Survey to test our hypothesis. Our empirical findings are in line with Lazear's theory and indicate that individuals who change between different types of education and acquire a more balanced set of skills are more likely to become entrepreneurs. Thus, the permeability of a country-specific educational system is one crucial determinant of entrepreneurship.
\end{abstract}

Keywords: Entrepreneurship, Jack-of-all-trades, Educational paths

\section{Introduction}

Country-specific educational systems offer different ways for individuals to pursue a certain educational level, as measured by the number of years in school. While climbing up the educational ladder, individuals can combine different types of skills or different types of education. In our paper, we focus on academic education as one type of education, and vocational education with systematic on-the-job training as another type. For example, an individual could reach an educational level worth fifteen years of education by going to a gymnasium (i.e. a high school) and then getting a bachelor's degree at a university of applied sciences. Alternatively, this person may reach an educational level worth fifteen years by going through an apprenticeship and then obtaining a bachelor's degree at a vocational college. The first educational

\footnotetext{
* Corresponding author: Uschi Backes-Gellner, Plattenstrasse 14, CH-8032 Zürich, Tel.: +41 4463442 81, backes-gellner@isu.uzh.ch

This study is partly funded by the Swiss Federal Office for Professional Education and Technology through its Leading House on the Economics of Education, Firm Behaviour and Training Policies. We would like to thank the Swiss Federal Statistical Office for data provision.
} 
path would combine different types of education, while the second would be a pure vocational path. Thus, individuals not only have to decide on their level of education but also have to choose the path they take to get there.

This paper investigates whether individuals who want to become entrepreneurs systematically choose educational paths that are different than the ones chosen by those who become employees. Thus, we are not concentrating on the relation between an individual's level of education and the probability that he or she will become an entrepreneur, a question that has frequently been analyzed in previous literature. Our paper, instead, is about differences in individuals' educational paths.

We use Lazear's jack-of-all-trades theory (Lazear, 2005) to explain why we expect a systematic relationship between educational paths and the likelihood that someone will become an entrepreneur or an employee. This theory states that (potential) entrepreneurs are characterized by a balanced skill set, while (potential) employees specialize in one type of skill. Applying this theory to our problem of systematic differences in individuals' educational paths, we expect (potential) entrepreneurs to follow educational paths that combine different types of education. By contrast, we expect (potential) employees to follow specialized educational paths.

To test this hypothesis we use data from the Swiss Labor Force Survey (SLFS) and find that the theoretical predictions are borne out in the data. Thus, this paper also provides another test of Lazear's jack-of-all-trades theory that is slightly different than the original skills analysis but proves to be valuable in our context as well.

Previous studies have not looked into the relationship between different types of educational paths and entrepreneurship; they have only focused on the effect of different levels of education on entrepreneurship. Thus, our results are innovative, and they carry novel and important policy implications. Our findings suggest that educational systems that enable their population to switch from one type of education to another encourage entrepreneurship. The opposite is true for educational systems that hamper changes in the type of education for individuals climbing up the educational ladder. Thus, an analysis of a nation's entrepreneurship climate also has to include the permeability between different educational tracks and, associated with this, the probability that individuals will actually move between different educational tracks. In this sense, this paper also provides an important contribution to entrepreneurship research.

The structure of this paper is as follows: The next section gives a description of Lazear's jack-of-all-trades theory and the hypothesis we test. Section 3 provides a discussion of the available empirical literature, an explanation of the chosen estimation method for analyzing the decision to become an entrepreneur versus an employee, and an overview of the data we used for empirical analyses, i.e. the Swiss Labor Force Survey (SLFS). Section 4 presents the results of the empirical analysis, and section 5 provides a discussion of the empirical evidence. Section 6 concludes. 


\section{Educational paths and entrepreneurship: A theoretical analysis based on Lazear's jack-of-all-trades theory}

According to Lazear's entrepreneurship model, potential entrepreneurs choose a broader educational path than potential employees. To illustrate the jack-of-alltrades explanation he uses a theoretical model based on two types of skills, $\mathrm{x}_{\mathrm{A}}$ and $\mathrm{x}_{\mathrm{B}}$. In our application, skill type $\mathrm{x}_{\mathrm{A}}$ represents academic skills individuals gain during full-time education in schools or colleges, and $\mathrm{x}_{\mathrm{B}}$ represents vocational skills individuals gain by apprenticeship or higher vocational training with large components of on-the-job and applied training.

According to Lazear (2005), potential employees need specialized skills and therefore concentrate on the one skill that they do best, i.e. they invest time and effort in improving this one type of skill (either $\mathrm{x}_{\mathrm{A}}$ or $\mathrm{x}_{\mathrm{B}}$ ). Their earnings are based on their best skill and are given by

$$
\mathrm{w}_{\text {Employee }}=\max \left(\mathrm{x}_{\mathrm{A}}, \mathrm{x}_{\mathrm{B}}\right)
$$

Entrepreneurs, on the contrary, need a broad spectrum of balanced skills to become successful and thus invest in different types of skills to keep their skill bundle balanced. Their earnings are restricted by their weakest skill and depend on the market value of entrepreneurial activities:

$$
\mathrm{w}_{\text {Entrepreneur }}=\lambda \min \left(\mathrm{x}_{\mathrm{A}}, \mathrm{x}_{\mathrm{B}}\right)
$$

where $\lambda \geq 1$ is a parameter for the market value of entrepreneurial activities. It is higher if entrepreneurial activities are valued more in a country or market (for example, because the number of potential entrepreneurs is lower) and lower if entrepreneurial activities are valued less in a country (for example, because there is no demand for a certain type of business).

Therefore, according to Lazear (2005), rational individuals decide to become entrepreneurs if, and only if, their entrepreneurial earnings are higher than their employee earnings would be. That is, individuals become entrepreneurs when

$$
\lambda \min \left(x_{A}, x_{B}\right)>\max \left(x_{A}, x_{B}\right) .
$$

This condition is visualized in a simple diagram given in Figure 1. If individuals have completely balanced skills $\left(\mathrm{x}_{\mathrm{A}}=\mathrm{x}_{\mathrm{B}}\right)$, then, according to the model, they decide to become entrepreneurs. However, if the entrepreneurial premium $\lambda$ is larger than 1 , even individuals without completely balanced skills will become entrepreneurs. This relation is characterized by the shaded area in Figure 1 . If $\lambda$ increases, both lines move to the outside, the area in which it pays to become an entrepreneur increases, and more people decide to become entrepreneurs. If, on the contrary, there is no premium for entrepreneurial skills, i.e. $\lambda$ is equal to 1 , both lines overlap with the $45^{\circ}$ 
line and no one decides to become an entrepreneur. Because the minimum of any combination of the two skills can never exceed the maximum of the combination, the condition for individuals to become entrepreneurs never holds. Figure 1 also illustrates that given any $\lambda$, individuals with more balanced skill bundles, i.e., with skill combinations closer to the $45^{\circ}$ line, are more likely to become entrepreneurs.

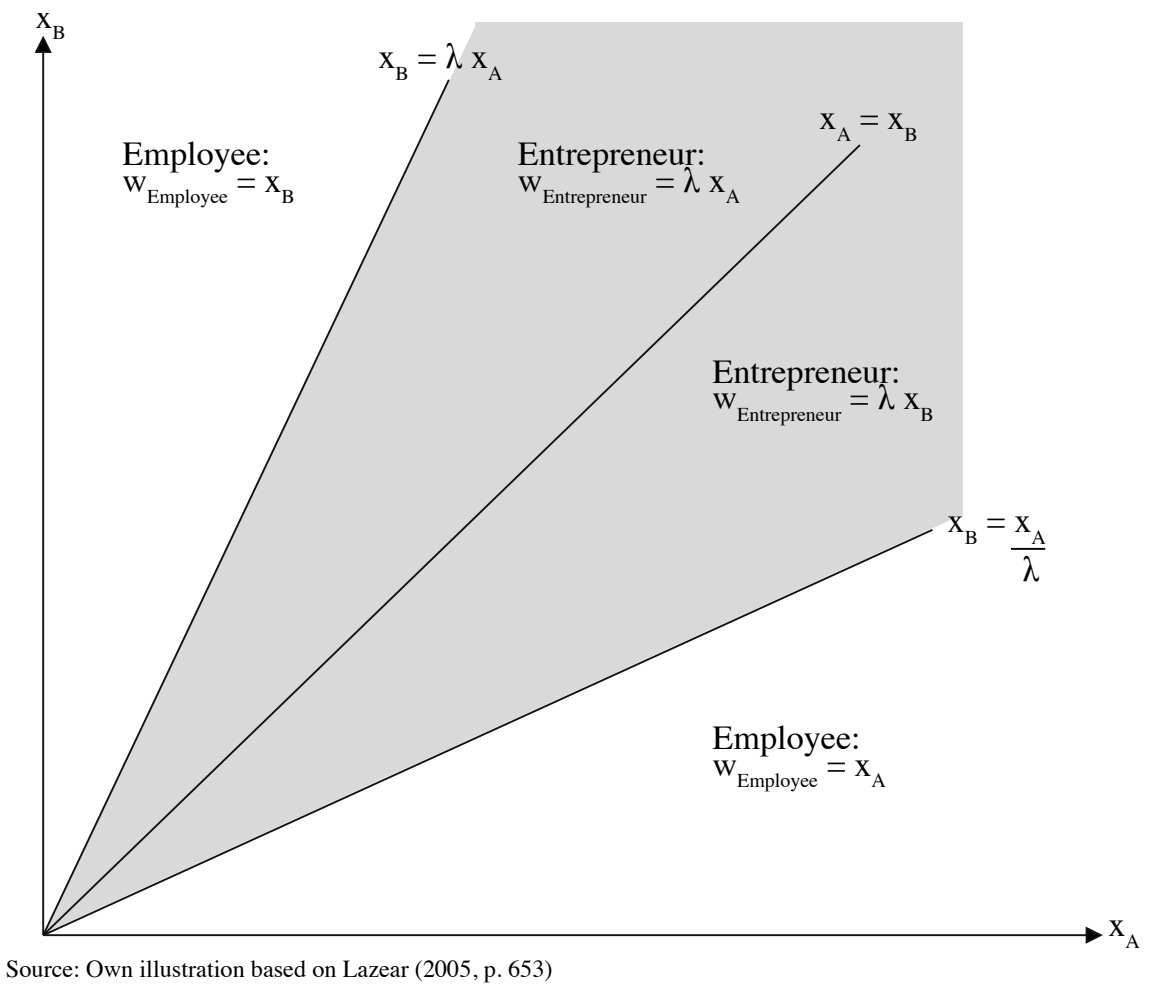

Figure 1: Entrepreneurship decision

Applying Lazear's model to our question of different educational paths, we expect that individuals who are interested in becoming entrepreneurs follow a more balanced investing strategy, i.e. they choose mixed educational paths; individuals who are interested in becoming employees follow a specialized investment strategy and choose specialized educational paths. For example, for individuals who, in their first educational step, finished apprenticeship training, a specialized investment strategy would be to strengthen the skill they already acquired and therefore attend a higher vocational school in the next step, while a balanced investment strategy would be to strengthen their weaker skill and therefore switch to an academic education in the next step. As another example, for individuals who finished a gymnasium (i.e. a high school) in their first step, a specialized investment strategy would be to stay with 
their already strong skill and therefore obtain a university degree, while a balanced investment strategy would be to strengthen their weaker skill and therefore switch to vocational training.

Thus, following Lazear's model, we expect employees to successively specialize with any additional human capital investment, and we expect entrepreneurs to go broader with any additional human capital investment. We assume that all educational paths combining academic and vocational education represent a balanced investment strategy. Along the same line, we also assume that all mixed educational paths starting with a vocational education focused on one occupation and followed by an academic education, which is by nature not concentrated on any particular occupation, reflect a broadening investment strategy leading toward a more balanced set of skills. Thus, our general hypothesis is:

Individuals who specialize during their educational paths are less likely to become entrepreneurs than individuals who broaden their skill set in their educational path (with the level of education kept constant).

\section{Empirical analyses on Lazear's jack-of-all-trades theory}

\subsection{Existing evidence}

Although no empirical study so far has looked at the relation between different educational paths and entrepreneurship, Lazear's theory has been tested a number of times with other empirical studies. All studies find more or less strong evidence in favor of the jack-of-all-trades model. In his own study, Lazear $(2004,2005)$ uses data on Stanford alumni to investigate how the education of today's entrepreneurs and employees differed during their years of study. He shows that individuals who chose a broader curriculum are more likely to become entrepreneurs and to start businesses (Lazear, 2005, p. 676). He concludes that entrepreneurs are jacks-of-alltrades, meaning they acquire a variety of different but balanced skills, as opposed to employees, who keep specializing during their career. More recently, a number of authors have been testing the predictions of parts of the jack-of-all-trades theory in various educational settings and with different types of data. These studies focus on work experience, different educational levels, skill sets, and the number of roles a person has worked in. The evidence is mixed. Strong support for Lazear's model is found in Backes-Gellner \& Moog (2008), Baumol (2004), Davidsson \& Honig (2003) and Wagner $\left(2003,2006^{1}\right)$, who find that people completing a more diverse education are more likely to become entrepreneurs. By contrast, Astebro (2006) does not observe differences in the educational behavior of entrepreneurs and employees.

1 However, Davidsson \& Honig (2003) and Wagner (2003, 2006) only consider nascent entrepreneurs in their studies. According to them, a more accurate analysis is hereby possible, since normally, as in Lazear (2005), only successful businesses are considered, and therefore the results might be biased. People who either plan to become self-employed or are currently building their own company are defined as nascent entrepreneurs (Wagner, 2003, 2006). 
Nevertheless, Lazear's finding that people with a more diverse career are more likely to become entrepreneurs is also supported by various authors using different data: by Astebro \& Thompson (2007) with Canadian data, by Baumol (2004) with U.S. and international data, by Davidsson \& Honig (2003) with Swedish data. Silva (2007), in addition, raises the question of whether being a jack-of-all-trades is an inherent skill.

In our paper, we build on this evidence and study whether a particular combination of certain types of education, namely the combination of vocational and fulltime academic education in an individual's educational path, also has an influence on the likelihood that he or she will become an entrepreneur. In analogy to Lazear's original model for two skills, we expect that entrepreneurs need two types of education, i.e. vocational skills gained by training on the job, and more abstract and analytical skills gained by full-time education. First evidence suggesting such a relationship is provided by the study of Tuor \& Backes-Gellner (2010) on complete educational paths. The authors, for the first time, point out that individuals with mixed educational paths are more likely to be entrepreneurs. Nevertheless, their study focuses on earnings and risk-return trade-offs of different educational paths and does not investigate the probability of one's becoming an entrepreneur or employee. But in the following empirical analysis, we build on their classification of different types of education and educational paths. We first give an overview of the data set. Second, we provide a detailed description of our variables and descriptive statistics. Third, we explain our estimation method, which we use to analyze the likelihood that someone will become an entrepreneur.

\subsection{The Swiss Labor Force Survey (SLFS)}

The data we used stemmed from the Swiss Labor Force Survey (SLFS). The SLFS is a household survey of the permanent resident population of Switzerland starting at the age of 15. The Federal Statistical Office (FSO) has conducted the survey annually since 1991, and aims to collect information about individuals' working lives and the labor market in general. Data collection is done through household surveys by phone. The sample size since 2001 is about 33,000 people (before that around 16,000) (FSO, 2008a). Accordingly, each person in the data set represents, on average, 130 members of the permanent resident population aged 15 or older in Switzerland (FSO, 2004). The SLFS is a rotating and unbalanced panel. A chosen person stays in the panel for five consecutive years before he or she is replaced. In other words, every year, about $20 \%$ of the individuals in the survey are substituted with new ones. Because the sampling is conducted randomly, the estimation methods basically remain the same (Wooldridge, 2002, pp. 577-581).

In this study, we include full-time employed Swiss people only; we exclude unemployed, non-employed and foreign people. Because we assume that non-Swiss individuals are more likely to have been educated in a different educational system, we do not include them in our analysis. The classification of foreigners' education into a particular educational path that we specifically base on Switzerland would be 
too difficult and arbitrary. In addition, we restrict the sample to people aged 20 to 64 with educational paths leading to a tertiary degree. This allows us to clearly analyze educational level and composition effects. Concerning our key independent variables, i.e. the educational paths, the survey questions were extended beyond 1999 . Therefore, our econometric analysis is based on data from 1999 to 2005.

The Swiss Labor Force Survey is particularly suitable for our study because its education data are collected annually. Additionally, the data set provides rich information that we can use to categorize workers into entrepreneurs and employees.

\subsection{Definition of main variables}

Following Lazear (2005), several types of entrepreneurs can be distinguished when testing his theoretical predictions. The different entrepreneurship definitions are summarized in Table 1.

A first definition (Entrepreneur 1: Ownership structure) aims to identify the differences between entrepreneurs and employees based on the ownership structure, not on the performed tasks. Within this definition we define individuals as entrepreneurs if they own a company (Ahmad \& Seymour, 2008, p. 12). Therefore, we consider all self-employed individuals or employees of their own company - whether or not the company has other employees - to be entrepreneurs.

A second definition following Lazear's approach to identify entrepreneurs depends on whether workers have a controlling or major management function (Entrepreneur 2: Lazear definition). In this case, Lazear differentiates between entrepreneurs, selfemployed with employees, and members of the management board, on the one hand, and employees and self-employed without employees, on the other. Self-employed without employees are not counted as entrepreneurs in this definition because they do not need to manage others and therefore do not need the same amount of overview and skills as entrepreneurs. This definition is exceptionally broad. Particularly when comparing with other entrepreneurship research, we have to interpret the empirical findings with great care when using this definition.

Table 1: Four Definitions of Entrepreneurs (EP)

\begin{tabular}{|l|c|c|c|c|}
\hline $\begin{array}{c}\text { Definition } \\
\text { criterion } \\
\text { professional }\end{array}$ & $\begin{array}{c}\text { EP 1: } \\
\text { Ownership } \\
\text { structure }\end{array}$ & $\begin{array}{c}\text { EP 2: } \\
\text { Lazear } \\
\text { definition }\end{array}$ & $\begin{array}{c}\text { EP 3: } \\
\text { Lazear } \\
\text { definition } \\
\text { applied to CH }\end{array}$ & $\begin{array}{c}\text { EP 4: } \\
\text { Management } \\
\text { position }\end{array}$ \\
\hline $\begin{array}{l}\text { Self-employed / employee of own } \\
\text { company with other employees }\end{array}$ & 1 & 1 & 1 & Not included \\
\hline $\begin{array}{l}\text { Self-employed / employee of own } \\
\text { company without other employees }\end{array}$ & 1 & 0 & 1 & Not included \\
\hline Employee & 0 & 0 & 0 & 0 \\
\hline Employee in management position & 0 & 1 & 1 & 1 \\
\hline
\end{tabular}

Source: own illustration 
The third definition (Entrepreneur 3: Lazear definition applied to $\mathrm{CH}$ ) is an extension of Lazear's model, taking into account that the empirical analysis is done with Swiss data where there are a large number of self-employed individuals accounting for a large part of the economy. Thus, we assume that self-employed without any other employees also need typical entrepreneurial skills and require a balanced set of skills. Thus, people who are either self-employed or employees of their own company - whether or not they have other employees - are coded 1.

For the fourth option (Entrepreneur 4: Management position) we look at employees only. Because the classification of the self-employed is most ambiguous, we exclude them in this definition to find out whether the results still hold for this reduced sample of workers. This narrow definition, focusing on employees only, increases the clarity of the respective results, but also reduces the sample size.

Regarding the independent variables, we focus on our explanatory variables, «educational paths», and all individuals with a tertiary degree as their highest educational level. Tuor \& Backes-Gellner (2010) have demonstrated the importance of using complete educational paths instead of solely relying on the highest educational degree. The focus on complete educational paths is possible because in our sample, in every year, individuals are asked to report not only their highest educational degree but also all educations completed to get there. Therefore, using this data, we can define the various educational paths that are important for this analysis. Figure 2 gives an overview of the different educational paths. ${ }^{2}$ In Table 2 we provide definitions of all educational paths ordered by degree of specificity of the investment strategy according to hypothesis 1 .

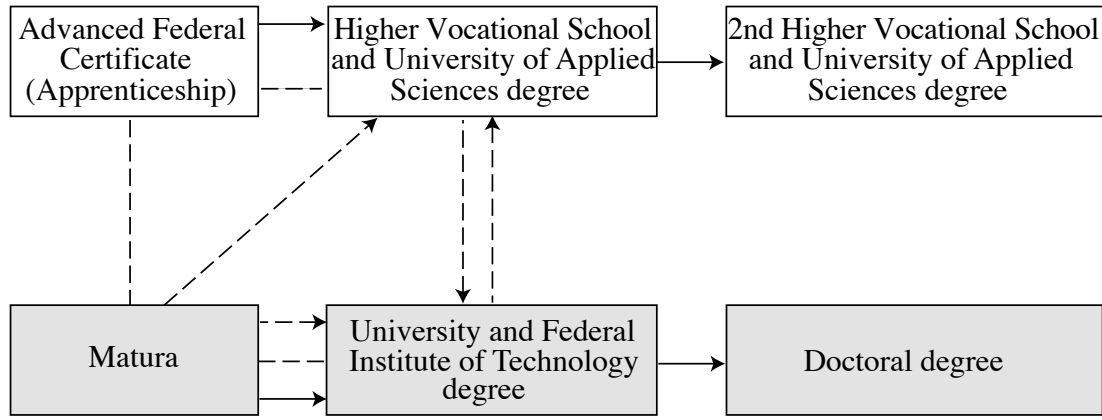

Notes

$\square$ vocational education - straight educational paths

$\square$ academic education $\quad--\cdot$ mixed educational paths

Source: own illustration

Figure 2: Overview of educational paths

2 In Appendix B, we provide a description of the different educational levels and educational types that are possible components of individuals' educational paths. A comprehensive descriptive overview of all dependent and independent variables is given in Table A1 in Appendix A. 
We categorize individuals depending on whether they have taken a purely vocational, a purely academic or a mixed educational path.

\section{High Degree of Specialization}

A vocational path is strongly based on on-the-job training and applied schooling. A vocational specialized path (voc) represents an educational career with an apprenticeship and a higher vocational education/university of applied sciences degree. This educational path is used as a reference category in our multivariate data analysis because the majority of individuals in our sample $(49.60 \%)$ choose this path. The different proportions in the various paths can be seen in Figure A1 in Appendix A. Also, in this context, there are people having completed two of the aforementioned higher education paths. An example is an individual who has attended a higher vocational school after the apprenticeship and then decided to obtain a degree at a university of applied sciences. This path will be denoted as a double vocational specialized path (voc+voc). Both educational paths include vocational education only and thus represent highly specialized paths in the sense of Lazear's entrepreneurship model. We further classify individuals who attended gymnasium and then obtained a degree from a university or a federal institute of technology as individuals with an academic educational path, referred to as academic specialized path (acad). This educational path represents a partly specialized strategy because they concentrate on one type of skill (academic but not vocational), but these skills are more generalizable than vocational skills, so they may be a little less specialized than pure vocational paths. Nevertheless, these paths are specialized and are thus expected to be similar to pure vocational paths.

\section{Medium Degree of Specialization}

Individuals with a purely academic path, in addition, have the possibility of obtaining a doctoral degree. We assume that although obtaining a doctoral degree may involve specializing in a field of study, it also broadens the total skill set because, in the context of Swiss universities, it also includes teaching experience and learning how to give a presentation and how to organize conferences or a project. Thus, if individuals obtain an additional doctoral degree, they followed an education path representing a balanced investment strategy and are referred to as academic balanced path (acad+acad).

Furthermore, people can choose to follow a mixed educational path. On the one hand, people have the option to start with an academic education and afterward switch to vocational education. These are, for example, individuals who attended a gymnasium first and then a higher vocational education and training school or a university of applied sciences second. This path is considered to be balanced because it combines different types of education. We refer to it as a mixed balanced path with academic entry (M_acad+voc). If an individual follows a purely academic 
path first and then, after having attained a higher academic educational degree, switches to a vocational education, i.e. attends a higher vocational education and training school or a university of applied sciences, we also assume this to be a balanced path and refer to it as a mixed balanced path with double academic entry ( $\mathrm{M}_{-}$ acad+acad+voc). Regarding the degree of specialization, these paths are balanced and are thus expected to be similar to the academic balanced path (acad+acad).

\section{Low Degree of Specialization (Balanced Educational Path)}

On the other hand, people have the option to follow mixed educational paths by switching to academic education after finishing an apprenticeship, i.e., after a vocational entry. This path is called mixed balanced path with vocational entry ( $\mathrm{M}_{-}$ voc+acad). If workers first followed a purely vocational educational path, i.e., after apprenticeship they attended a higher vocational education and training school or a university of applied sciences, but then switched to academic education and obtained a university or federal institute of technology degree, then these workers have taken a mixed balanced path with double vocational entry (M_voc+voc+acad). Although all educational paths combining academic and vocational education represent a balanced investing strategy, we suggest that a mixed educational path with initial vocational followed by academic education better reflects the idea of going broader with any additional human capital investment.

In addition to our explanatory variables, we use a number of control variables. As in most similar studies, we apply workers' labor market experience as a control variable (among others: Astebro, 2006; Astebro \& Thomson, 2007; Honig, 1996; Robinson \& Sexton, 1994). ${ }^{3}$ Because workers' age is highly correlated with their labor market experience (0.7343), we do not include the former variable in the empirical analysis. In line with similar papers, further control variables, in the estimation model referred to as individual characteristics, are gender, children and marital status (among others: Astebro \& Thomson, 2007; Backes-Gellner \& Moog, 2008; Lazear, 2005; Wagner, 2003, 2006). Gender and children are two dummy variables taking a value of 1 if a person is male and has children below the age of 15 , respectively. Regarding marital status, the variable can take four different values: single, married (reference), divorced and widowed. Furthermore, some general characteristics are included as controls. The variables include the geographical region of the workplace, where the region of Zurich is used as a reference category and dummy variable for each year. These yearly dummies are included in order to control for the development of the entrepreneurship rate. Definitions of and further information pertaining to the described variables are also given in Table A1 in Appendix A.

3 The Swiss Labor Force Survey (SLFS) especially asks the interviewed person how long they have been in the labor force without a major interruption. Therefore, the variable for labor market experience does not need to be constructed by age and length of education. 
Table 2: Definition of Educational Paths

\begin{tabular}{|c|c|c|}
\hline \multicolumn{3}{|c|}{ Specialized } \\
\hline & voc & $\begin{array}{l}\text { Vocational specialized path: } \\
\text { Advanced Federal Certificate (Apprenticeship) } \\
+ \text { Higher Vocational School / University of Applied Sciences }\end{array}$ \\
\hline & voc+voc & $\begin{array}{l}\text { Double vocational specialized path: } \\
\text { Advanced Federal Certificate (Apprenticeship) } \\
+ \text { Higher Vocational School / University of Applied Sciences } \\
\text { + } 2 \text { nd Higher Vocational School / University of Applied Sciences }\end{array}$ \\
\hline & acad & $\begin{array}{l}\text { Academic specialized path: } \\
\text { «Matura» } \\
+ \text { University / Federal Institute of Technology }\end{array}$ \\
\hline & acad+acad & $\begin{array}{l}\text { Academic balanced path: } \\
\text { «Matura» } \\
+ \text { University / Federal Institute of Technology } \\
\text { + doctoral degree }\end{array}$ \\
\hline & M_acad+voc & $\begin{array}{l}\text { Mixed balanced path with academic entry: } \\
\text { «Matura» } \\
+ \text { Higher Vocational School / University of Applied Sciences }\end{array}$ \\
\hline & M_acad+acad+voc & $\begin{array}{l}\text { Mixed balanced path with double academic entry: } \\
\text { «atura» } \\
\text { + University / Federal Institute of Technology } \\
\text { + Higher Vocational School / University of Applied Sciences }\end{array}$ \\
\hline & M_voc+acad & $\begin{array}{l}\text { Mixed balanced path with vocational entry: } \\
\text { Advanced Federal Certificate (Apprenticeship) + «Matura» } \\
\text { + University / Federal Institute of Technology }\end{array}$ \\
\hline$\nabla$ & M_voc+voc+acad & $\begin{array}{l}\text { Mixed balanced path with double vocational entry: } \\
\text { Advanced Federal Certificate (Apprenticeship) } \\
+ \text { + Higher Vocational School / University of Applied Sciences } \\
\text { + University or Federal Institute of Technology }\end{array}$ \\
\hline
\end{tabular}

Balanced

Source: Own illustration.

Note: Educational paths are categorized according to the degree of specialization of the skill set obtained through them. Educational paths separated by dashed lines are very similar and within groups, ordering is random. Pronounced differences are assumed between groups.

\subsection{Estimation model}

To empirically analyze the likelihood of becoming an entrepreneur, depending on different educational paths, we used a probit regression because the dependent variable «entrepreneur» is a binary variable. «Entrepreneur» has a value of 1 if the person is an entrepreneur and 0 if an employee. The basic model we estimate to analyze the likelihood of becoming an entrepreneur is as follows:

Entrepreneur $=\beta_{1} *$ educational paths $+\beta_{2} *$ work experience $+\beta_{3} *(\text { work experience })^{2}$ $+\beta_{4} *$ individual characteristics $+\beta_{5} *$ general characteristics $+\varepsilon$ 
As mentioned in section 3.3, the key independent variables are the dummy variables indicating the different educational paths. The formerly described control variables «work experience», «individual characteristics» and «general characteristics» are also included. The error term $\varepsilon$ in the equation is assumed to follow a standard normal distribution.

\section{Results for the likelihood of becoming an entrepreneur}

Table A2 provides empirical results for our estimation equation (1). To make the interpretation of the results more intuitive, the coefficients in the table refer to the average of the marginal effects calculated for each person in the data. As expected, in general, we find a significantly positive relation between the likelihood of becoming an entrepreneur and having followed a mixed educational path, in comparison to a specialized educational path. This result is most pronounced for the third entrepreneurship definition (Lazear definition applied to $\mathrm{CH}$ ) and the fourth (management position), which, as we have argued previously, are the most appropriate definitions for Switzerland. Therefore, we focus on these two estimations in the following interpretations.

Although there is a clear pattern demonstrating a positive relation between mixed educational paths and entrepreneurship, there is some variation within the group of mixed educational paths, which are all compared to the reference category (vocational specialized path).

First, the coefficient is strongest for workers with a mixed balanced path with a vocational entry $\left(M \_v o c+a c a d\right)$. An example of such a worker would be an individual with apprenticeship training as a computer specialist that obtains, for example, a business degree later on. This individual has the specific skills required for doing computer work as well as the general knowledge of how to handle a business. Accordingly, and as expected, we also find a significantly higher probability of becoming an entrepreneur for workers with a mixed balanced path with double vocational entry (M_voc+voc+acad).

Second, the coefficient for a mixed balanced path with academic entry $\left(M_{-}\right.$ $a c a d+v o c)$, is positive but not significant, while the coefficient for a mixed balanced path with double academic entry $\left(M \_a c a d+a c a d+v o c\right)$ is still highly significant and positive.

Third, as expected, workers with academic specialized paths (acad) are neither more nor less likely to become entrepreneurs. However, for academic balanced paths $(a c a d+a c a d)$ we find, as expected, a significant and positive coefficient for becoming an entrepreneur. This result supports our suggestion that obtaining a doctoral degree represents a balanced investment strategy.

Carrying forward these empirical results to the entrepreneurship-diagram introduced in Figure 1, we provide a positioning of different educational paths in the twodimensional entrepreneurship plane (cf. Figure 3). 


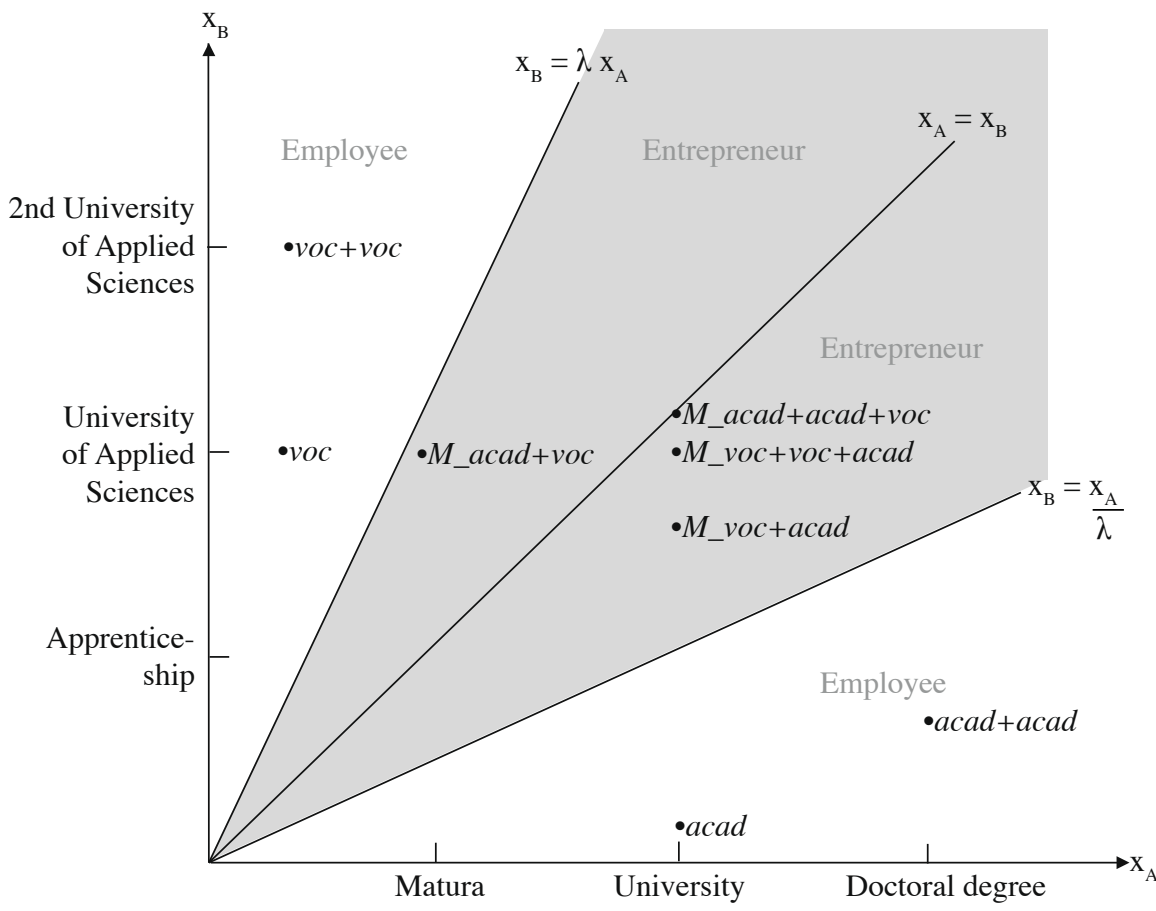

Source: own illustration based on: Lazear (2005, p. 653)

Figure 3: Educational paths and entrepreneurship decisions

With respect to our control variables, we found results similar to previous studies. We found a concave effect of work experience like Lazear (2005) and Wagner (2003). The effect of work experience is positive but declines over time. Consistent with other papers (Astebro \& Thompson, 2007; Honig, 1996; Astebro, 2006), the negative coefficients of the variables single household and widowed indicate that married people have a higher likelihood of becoming entrepreneurs. The variable men has a significant positive effect, meaning that males are more likely to become entrepreneurs than females. This finding is also consistent with previous studies. ${ }^{4}$ If the estimation is done separately for men and women, the findings are robust for men, but for women, only a few variables are significant. The reason for this probably lies in the small number of females in our sample, and shows that the results are driven by men. Noticeable, though, is that the variable children remains positive and significant, regardless of whether we carry out a joint or separate estimation. This result contradicts the negative effect of children found by Backes-Gellner \& Moog (2008) but supports the findings of, among others, Robinson \& Sexton (1994).

4 Lazear (2005), Wagner (2003, 2006), Honig (1996) and Backes-Gellner \& Moog (2008) among others find the same positive correlation. 
Unfortunately, it is not possible to directly compare our empirical results with the coefficients of other studies (Wagner, 2003, 2006; Silva, 2007; Lazear, 2005). The reason is that these studies use the number of different tasks as explanatory variables. This measure is conceptually different from the types of education we use in our study. Nevertheless, those studies and ours are similar in that they all provide evidence supporting the hypothesis that individuals are more likely to become entrepreneurs if they have a more balanced set of skills or education.

\section{Discussion and Limitation of Results}

We are aware of characteristics that potentially have an impact on the probability of taking a mixed educational paths and becoming an entrepreneur. If, for instance, more able or motivated individuals are the ones more likely to choose a mixed educational path and the ones more likely to become entrepreneurs, then we would also find a correlation between mixed educational paths and entrepreneurship. Although we cannot completely exclude other explanations (i.e., motivation or ability) why individuals with mixed educational paths are more likely to become entrepreneurs, we assume that there is also a direct effect from entrepreneurs following mixed educational paths. Given the relatively high length of study associated with mixed educational paths, we would not expect entrepreneurs to follow these paths if they did not benefit in terms of higher labor market success.

However, we tested the potential endogeneity of individuals' initial educational decision. We constructed a variable ${ }^{5}$ using the corresponding percentage of juveniles getting a Matura degree for each canton and year. ${ }^{6}$ The Swiss cantons are systematically different in terms of their education patterns. For example, in 2000 , the proportion of youths who had acquired a university entrance certificate was $27.6 \%$ in «Ticino» (the Italian-speaking part of Switzerland) and $28.0 \%$ in Geneva (a region in the French-speaking part of Switzerland), while the proportion was only $12.0 \%$ in Lucerne (a region in the German-speaking part of Switzerland). ${ }^{7}$ We assume the cantonal percentage of juveniles getting a Matura degree to be correlated with individuals' initial education decisions but not with individuals' average ability and labor market outcomes (including the probability of becoming an entrepreneur). Thus, we use the Matura ratio as a determinant for the decision to get a Matura degree. Table A3 shows the empirical results of the probit regression. As the Matura ratio significantly influences the likelihood of getting a Matura degree, we interpret this as evidence for a potential endogeneity of individuals' initial education decision. We expect similar results for further educational decisions. Thus, an instrumental

5 To construct the instrumental variable we assumed that Swiss teenagers, on average, get their Matura degree at the age of 20 and we were then able to assign persons the corresponding average Matura ratio of their canton.

6 The data used to construct the instrumental variable was released by the Swiss Federal Statistical Office in the Statistical Yearbooks of Switzerland 1940-2000 (Statistische Jahrbücher der Schweiz 1940-2000, Bundesamt für Statistik).

7 Cf. http://www.bfs.admin.ch/bfs/portal/de/index/themen/15/06/key/ind12.indicator.12106.html 
variable approach would be appropriate in order to methodologically consider the potential endogeneity problem. Unfortunately, neither our dataset nor other currently publicly available data provide appropriate instruments for each educational step, and, thus, for each educational path. Further research on educational paths might provide more insight into the importance of the potential endogeneity of individuals' educational decision. Nevertheless, we argue that our theoretical reasoning and the presented empirical evidence provide strong evidence for individuals with mixed educational paths to be more likely to become entrepreneurs.

To summarize, our empirical results support our hypothesis based on Lazear's theory of entrepreneurship. The findings indicate that individuals who have followed a mixed educational path (who combine academic and vocational education) are more likely to become entrepreneurs than those who invested in vocational education only. Furthermore, the likelihood of becoming an entrepreneur is higher for individuals who have first completed a vocational and then an academic education than for those who have completed the education the other way around. Since the latter start with a broad academic education and then specialize, their skill combination fits well into Lazear's model because the model expects employees to successively specialize with any additional human capital investment, whereas entrepreneurs would go broader with any additional human capital investment.

\section{Conclusion}

We have examined whether individuals who become entrepreneurs or employees follow systematically different educational paths to a given educational level. We use Lazear's jack-of-all-trades theory to derive how individuals' educational paths may differ. We expect that entrepreneurs aim at a balanced set of academic and vocational skills while employees specialize in either of the two. Thus, the likelihood of being an entrepreneur should be higher among individuals with mixed educational paths combining academic and vocational types of education. By contrast, we expect employees to follow the same type of education through their educational career because such a pure educational path allows them to specialize in their strongest qualification. Accordingly, the likelihood of becoming an entrepreneur should be lower for individuals with pure academic or pure vocational paths. We tested this hypothesis with the Swiss Labor Force Survey. The results indicate that entrepreneurs and employees indeed choose systematically different educational paths. Consistent with Lazear's theory, entrepreneurs choose mixed and more balanced educational paths, whereas employees choose pure and more specialized educational paths. Therefore, the likelihood of entrepreneurship could be increased by easing changes between different educational segments and allowing individuals to more easily switch from vocational to academic educational tracks and back again.

Switzerland, in this context, has an interesting educational system enabling a switch from one type of education to another and offering so-called «Passerellen» or official pathways leading from one segment of the educational system to the other. 
According to our theoretical considerations, Switzerland should therefore also have a comparatively high proportion of entrepreneurs. This is supported by data. For example, Eurostat ${ }^{8}$ shows an entrepreneurship rate of $14 \%$ for Switzerland in comparison to, e.g. $11 \%$ for Germany or $13 \%$ for the UK. Taking this argument further, the evidence suggests that the permeability of a country-specific system of education as opposed to strong demarcation lines between different types of education should be an important factor that explains differences in entrepreneurship rates. Future entrepreneurship research should thus also study the permeability of educational systems as one important factor to increasing the national entrepreneurship rate. In previous research, the focus was mainly on the level of education, but our results clearly show that the level of education is not sufficient to study the preconditions an educational system has to have to foster entrepreneurship.

\section{Appendix A}

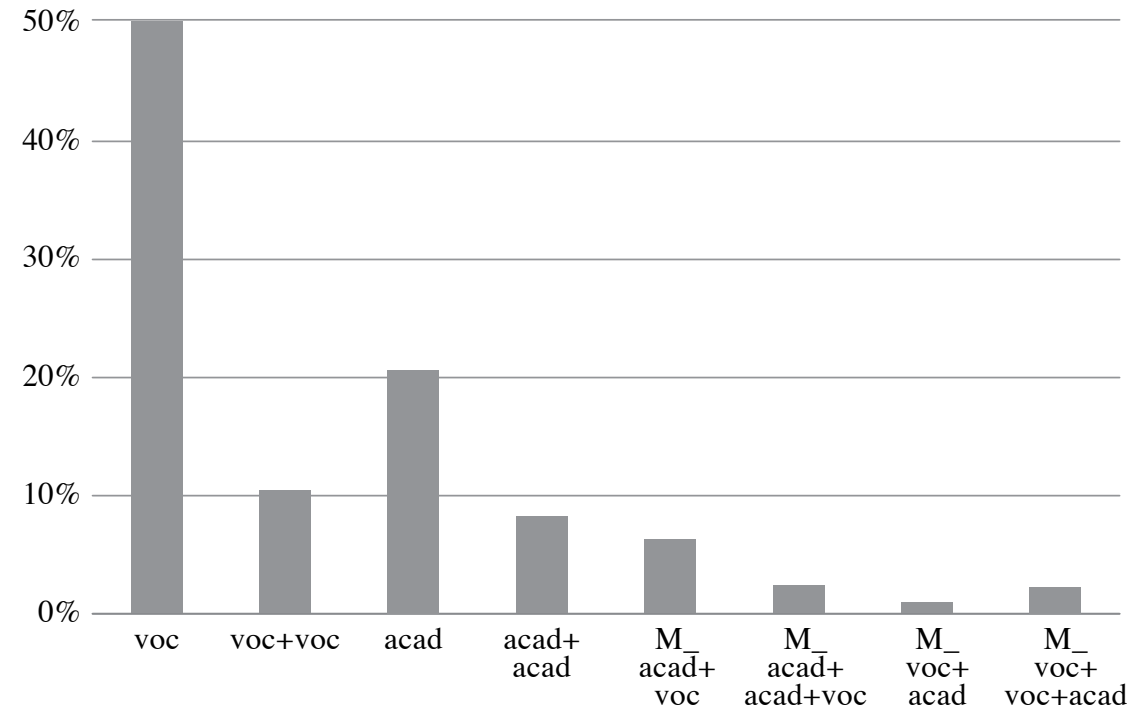

Source: own illustration based on Swiss Labor Force Survey, FSO

Figure A1: Participation rates of the different educational paths

8 http://epp.eurostat.ec.europa.eu/portal/page/portal/employment_unemployment_lfs/data/database 
Table A1: Descriptive Overview: Entrepreneur - Estimation

\begin{tabular}{|c|c|c|c|c|c|c|c|c|c|}
\hline \multirow{3}{*}{ VARIABLE } & \multirow{3}{*}{ DEFINITION OF VARIABLE } & \multicolumn{2}{|c|}{$\begin{array}{l}\text { Entrepreneur 1: } \\
\text { Ownership structure }\end{array}$} & \multicolumn{2}{|c|}{$\begin{array}{l}\text { Entrepreneur 2: } \\
\text { Lazear definition }\end{array}$} & \multicolumn{2}{|c|}{$\begin{array}{l}\text { Entrepreneur 3: } \\
\text { Lazear definition } \\
\text { applied to } \mathrm{CH}\end{array}$} & \multicolumn{2}{|c|}{$\begin{array}{c}\text { Entrepreneur 4: } \\
\text { Management position }\end{array}$} \\
\hline & & $\begin{array}{c}\text { Entre- } \\
\text { preneur } \\
\mathrm{N}=3,737\end{array}$ & $\begin{array}{l}\text { Employee } \\
\mathrm{N}=11,658\end{array}$ & $\begin{array}{c}\text { Entre- } \\
\text { preneur } \\
\mathrm{N}=6,950\end{array}$ & $\begin{array}{l}\text { Employee } \\
\mathrm{N}=8,445\end{array}$ & $\begin{array}{c}\text { Entre- } \\
\text { preneur } \\
\mathrm{N}=8,182\end{array}$ & $\begin{array}{l}\text { Employee } \\
\mathrm{N}=7,213\end{array}$ & $\begin{array}{c}\text { Entre- } \\
\text { preneur } \\
\mathrm{N}=4,445\end{array}$ & $\begin{array}{c}\text { Employee } \\
\mathrm{N}=7,213\end{array}$ \\
\hline & & $\begin{array}{c}\text { Mean } \\
\text { (Std. dev.) }\end{array}$ & $\begin{array}{c}\text { Mean } \\
\text { (Std. dev.) }\end{array}$ & $\begin{array}{c}\text { Mean } \\
\text { (Std. dev.) }\end{array}$ & $\begin{array}{c}\text { Mean } \\
\text { (Std. dev.) }\end{array}$ & $\begin{array}{c}\text { Mean } \\
\text { (Std. dev.) }\end{array}$ & $\begin{array}{c}\text { Mean } \\
\text { (Std. dev.) }\end{array}$ & $\begin{array}{c}\text { Mean } \\
\text { (Std. dev.) }\end{array}$ & $\begin{array}{c}\text { Mean } \\
\text { (Std. dev.) }\end{array}$ \\
\hline $\begin{array}{l}\text { Entrepreneur 1: } \\
\text { Ownership structure }\end{array}$ & $\begin{array}{l}\text { Dummy }=1 \text {, if self-employed or employee of his/her own } \\
\text { company with or without other employees }\end{array}$ & \multicolumn{2}{|c|}{$\begin{array}{c}0.2425 \\
(0.4286)\end{array}$} & & & & & & \\
\hline $\begin{array}{l}\text { Entrepreneur 2: } \\
\text { Lazear definition }\end{array}$ & $\begin{array}{l}\text { Dummy }=1 \text {, if self-employed or employee of his/her own } \\
\text { company with other employees, or member of the } \\
\text { management board }\end{array}$ & & & \multicolumn{2}{|c|}{0.4511} & & & & \\
\hline $\begin{array}{l}\text { Entrepreneur 3: Lazear } \\
\text { definition applied to } \mathrm{CH}\end{array}$ & $\begin{array}{l}\text { Dummy }=1 \text {, if self-employed or employee of his/her own } \\
\text { company with or without other employees, or member of } \\
\text { the management board }\end{array}$ & & & \multicolumn{6}{|c|}{$\begin{array}{c}0.5311 \\
(0.4990)\end{array}$} \\
\hline $\begin{array}{l}\text { Entrepreneur 4: } \\
\text { Management position }\end{array}$ & Dummy $=1$, if member of the management board & & & & & & & \multicolumn{2}{|c|}{$\begin{array}{c}0.3810 \\
(0.4856)\end{array}$} \\
\hline \multicolumn{10}{|l|}{ Educational paths } \\
\hline voc & $\begin{array}{l}\text { Dummy = } 1 \text {, if Advance Federal Certificate (Apprentice- } \\
\text { ship) and Higher Vocational School or University of } \\
\text { Applied Scieinces degree (Reference) }\end{array}$ & $\begin{array}{l}0.4996 \\
(0.5001) \\
\end{array}$ & $\begin{array}{c}0.4938 \\
(0.5000)\end{array}$ & $\begin{array}{c}0.4843 \\
(0.4998) \\
\end{array}$ & $\begin{array}{c}0.5042 \\
(0.5000)\end{array}$ & $\begin{array}{c}0.4934 \\
(0.5000) \\
\end{array}$ & $\begin{array}{l}0.4973 \\
(0.5000)\end{array}$ & $\begin{array}{c}0.4882 \\
(0.4999) \\
\end{array}$ & $\begin{array}{l}0.4973 \\
(0.5000) \\
\end{array}$ \\
\hline voc+voc & $\begin{array}{l}\text { Dummy }=1 \text {, if Advance Federal Certificate (Apprentice- } \\
\text { ship) and Higher Vocational School or University of } \\
\text { Applied Sciences degree and 2nd Higher Vocational } \\
\text { School or University of Applied Sciences degree }\end{array}$ & $(0.2818)$ & $(0.3104)$ & $(0.3053)$ & $(0.3026)$ & $(0.3000)$ & $(0.3081)$ & $(0.3141)$ & $(0.3081)$ \\
\hline acad & $\begin{array}{l}\text { Dummy }=1 \text {, if } \ll \text { Matura» and University or Federal } \\
\text { Institute of Technology degree }\end{array}$ & $\begin{array}{r}0.1635 \\
(-0.3699)\end{array}$ & $\begin{array}{c}0.217 \\
(-0.4122)\end{array}$ & $\begin{array}{c}0.1911 \\
(-0.3932)\end{array}$ & $\begin{array}{r}0.2147 \\
(-0.4106)\end{array}$ & $\begin{array}{c}0.1871 \\
(-0.3900)\end{array}$ & $\begin{array}{c}0.2232 \\
(-0.4164)\end{array}$ & $\begin{array}{c}0.207 \\
(-0.4052)\end{array}$ & $\begin{array}{c}0.2232 \\
(-0.4164) \\
\end{array}$ \\
\hline acad+acad & $\begin{array}{l}\text { Dummy }=1 \text {, if «Matura» and University or Federal } \\
\text { Institute of Technology and doctoral degree }\end{array}$ & $\begin{array}{l}0.1317 \\
(0.3382)\end{array}$ & $\begin{array}{c}0.0653 \\
(0.2470)\end{array}$ & $\begin{array}{l}0.1085 \\
(0.3110)\end{array}$ & $\begin{array}{c}0.0591 \\
(0.2358)\end{array}$ & $\begin{array}{l}0.1018 \\
(0.3024)\end{array}$ & $\begin{array}{l}0.0582 \\
(0.2342)\end{array}$ & $\begin{array}{l}0.0767 \\
(0.2662)\end{array}$ & $\begin{array}{c}0.0582 \\
(0.2342)\end{array}$ \\
\hline M_acad+voc & $\begin{array}{l}\text { Dummy }=1 \text {, if «Matura» and Higher Vocational School or } \\
\text { University of Applied Sciences degree }\end{array}$ & $\begin{array}{l}0.0575 \\
(0.2329)\end{array}$ & $\begin{array}{c}0.0637 \\
(0.2443)\end{array}$ & $\begin{array}{l}0.0515 \\
(0.2211)\end{array}$ & $\begin{array}{l}0.0710 \\
(0.2569)\end{array}$ & $\begin{array}{l}0.0565 \\
(0.2308)\end{array}$ & $\begin{array}{l}0.0688 \\
(0.2531)\end{array}$ & $\begin{array}{l}0.0556 \\
(0.2291)\end{array}$ & $\begin{array}{c}0.0688 \\
(0.2531)\end{array}$ \\
\hline
\end{tabular}




\begin{tabular}{|c|c|c|c|c|c|c|c|c|c|}
\hline M_acad+acad+voc & $\begin{array}{l}\text { Dummy }=1, \text { if } « \text { Matura } \gg \text { and University or Federal } \\
\text { Institute of Technology and Higher Vocational } \\
\text { School or University of Applied Sciences degree }\end{array}$ & $\begin{array}{l}0.0276 \\
(0.1637) \\
\end{array}$ & $\begin{array}{c}0.0217 \\
(0.1457) \\
\end{array}$ & $\begin{array}{c}0.0245 \\
(0.1545) \\
\end{array}$ & $\begin{array}{l}0.0220 \\
(0.1468) \\
\end{array}$ & $\begin{array}{l}0.0253 \\
(0.1570) \\
\end{array}$ & $\begin{array}{l}0.0207 \\
(0.1422) \\
\end{array}$ & $\begin{array}{l}0.0234 \\
(0.1512) \\
\end{array}$ & $\begin{array}{l}0.0207 \\
(0.1422) \\
\end{array}$ \\
\hline M_voctacad & $\begin{array}{l}\text { Dummy }=1 \text {, if Advance Federal Certificate } \\
\text { (Apprenticeship) and } \ll \text { Matura» and University or } \\
\text { Federal Institute of Technology degree }\end{array}$ & $\begin{array}{l}0.0094 \\
(0.0963)\end{array}$ & $\begin{array}{l}0.0091 \\
(0.0949)\end{array}$ & $\begin{array}{l}0.0114 \\
(0.1060)\end{array}$ & $\begin{array}{l}0.0073 \\
(0.0854)\end{array}$ & $\begin{array}{l}0.0106 \\
(0.1026)\end{array}$ & $\begin{array}{l}0.0075 \\
(0.0862)\end{array}$ & $\begin{array}{l}0.0117 \\
(0.1075)\end{array}$ & $\begin{array}{l}0.0075 \\
(0.0862)\end{array}$ \\
\hline M_voc+voc+acad & $\begin{array}{l}\text { Dummy }=1 \text {, if Advance Federal Certificate } \\
\text { (Apprenticeship) and Higher Vocational School or } \\
\text { University of Applied Sciences and University or } \\
\text { Federal Institute of Technology degree }\end{array}$ & $\begin{array}{l}0.0238 \\
(0.1523)\end{array}$ & $\begin{array}{l}0.0214 \\
(0.1446)\end{array}$ & $\begin{array}{l}0.0247 \\
(0.1554)\end{array}$ & $\begin{array}{l}0.0197 \\
(0.1388)\end{array}$ & $\begin{array}{l}0.0253 \\
(0.1570)\end{array}$ & $\begin{array}{l}0.0182 \\
(0.1335)\end{array}$ & $\begin{array}{l}0.0265 \\
(0.1608)\end{array}$ & $\begin{array}{l}0.0182 \\
(0.1335)\end{array}$ \\
\hline \multicolumn{10}{|l|}{ Work experience } \\
\hline Work experience * & Work experience per 10 years & $\begin{array}{l}2.2230 \\
(1.1136)\end{array}$ & $\begin{array}{l}1.8185 \\
(1.1504)\end{array}$ & $\begin{array}{l}2.1483 \\
(1.0896)\end{array}$ & $\begin{array}{r}1.7260 \\
(1.1718)\end{array}$ & $\begin{array}{r}2.1463 \\
(1.1101)\end{array}$ & $\begin{array}{l}1.6562 \\
(1.1490)\end{array}$ & $\begin{array}{l}2.0817 \\
(1.1031)\end{array}$ & $\begin{array}{l}1.6562 \\
(1.1490)\end{array}$ \\
\hline$\ldots$ squared & Work experience per 10 years squared & $\begin{array}{l}6.1816 \\
(5.3876)\end{array}$ & $\begin{array}{l}4.6301 \\
(5.0013)\end{array}$ & $\begin{array}{l}5.8023 \\
(5.1554)\end{array}$ & $\begin{array}{l}4.3520 \\
(5.0357)\end{array}$ & $\begin{array}{l}5.8386 \\
(5.2469)\end{array}$ & $\begin{array}{l}4.0631 \\
(4.8484)\end{array}$ & $\begin{array}{l}5.5502 \\
(5.1084)\end{array}$ & $\begin{array}{l}4.0631 \\
(4.8484)\end{array}$ \\
\hline \multicolumn{10}{|c|}{ Individual characteristics } \\
\hline Men & Dummy $=1$, if male & $\begin{array}{l}0.8603 \\
(0.3467)\end{array}$ & $\begin{array}{l}0.8192 \\
(0.3849)\end{array}$ & $\begin{array}{l}0.8745 \\
(0.3313)\end{array}$ & $\begin{array}{l}0.7918 \\
(0.4060)\end{array}$ & $\begin{array}{l}0.8645 \\
(0.3423)\end{array}$ & $\begin{array}{l}0.7891 \\
(0.4080)\end{array}$ & $\begin{array}{l}0.8679 \\
(0.3386)\end{array}$ & $\begin{array}{l}0.7891 \\
(0.4080)\end{array}$ \\
\hline Children & Dummy $=1$, if children (below the age of 15 ) & $\begin{array}{c}0.3631 \\
(0.4810)\end{array}$ & $\begin{array}{c}0.3193 \\
(0.4662)\end{array}$ & $\begin{array}{c}0.3898 \\
(0.4877)\end{array}$ & $\begin{array}{c}0.2806 \\
(0.4493)\end{array}$ & $\begin{array}{c}0.3718 \\
(0.4833)\end{array}$ & $\begin{array}{c}0.2824 \\
(0.4502)\end{array}$ & $\begin{array}{c}0.3791 \\
(0.4852)\end{array}$ & $\begin{array}{c}0.2824 \\
(0.4502)\end{array}$ \\
\hline \multicolumn{10}{|l|}{ Marital status } \\
\hline Single & Dummy $=1$, if single & $\begin{array}{c}0.2101 \\
(0.4074)\end{array}$ & $\begin{array}{c}0.3470 \\
(0.4760)\end{array}$ & $\begin{array}{l}0.2236 \\
(0.4167)\end{array}$ & $\begin{array}{c}0.3879 \\
(0.4873)\end{array}$ & $\begin{array}{c}0.2331 \\
(0.4228)\end{array}$ & $\begin{array}{l}0.4052 \\
(0.4910)\end{array}$ & $\begin{array}{l}0.2524 \\
(0.4344)\end{array}$ & $\begin{array}{c}0.4052 \\
(0.4910)\end{array}$ \\
\hline Married & Dummy $=1$, if married (Reference) & $\begin{array}{c}0.6620 \\
(0.4731)\end{array}$ & $\begin{array}{l}0.5511 \\
(0.4974)\end{array}$ & $\begin{array}{c}0.6714 \\
(0.4698)\end{array}$ & $\begin{array}{l}0.5012 \\
(0.5000)\end{array}$ & $\begin{array}{c}0.6511 \\
(0.4767)\end{array}$ & $\begin{array}{l}0.4952 \\
(0.5000)\end{array}$ & $\begin{array}{l}0.6418 \\
(0.4795)\end{array}$ & $\begin{array}{l}0.4952 \\
(0.5000)\end{array}$ \\
\hline Divorced & Dummy $=1$, if divorced & $\begin{array}{l}0.1193 \\
(0.3242)\end{array}$ & $\begin{array}{c}0.0925 \\
(0.2897)\end{array}$ & $\begin{array}{c}0.0973 \\
(0.2963)\end{array}$ & $\begin{array}{c}0.1004 \\
(0.3006)\end{array}$ & $\begin{array}{c}0.1079 \\
(0.3103)\end{array}$ & $\begin{array}{l}0.0889 \\
(0.2846)\end{array}$ & $\begin{array}{l}0.0983 \\
(0.2978)\end{array}$ & $\begin{array}{c}0.0889 \\
(0.2846)\end{array}$ \\
\hline Widowed & Dummy $=1$, if widowed & $\begin{array}{l}0.0086 \\
(0.0922)\end{array}$ & $\begin{array}{c}0.0094 \\
(0.0967)\end{array}$ & $\begin{array}{c}0.0078 \\
(0.0878)\end{array}$ & $\begin{array}{l}0.0104 \\
(0.1016)\end{array}$ & $\begin{array}{c}0.0079 \\
(0.0888)\end{array}$ & $\begin{array}{l}0.0107 \\
(0.1028)\end{array}$ & $\begin{array}{l}0.0074 \\
(0.0859)\end{array}$ & $\begin{array}{c}0.0107 \\
(0.1028)\end{array}$ \\
\hline
\end{tabular}




\begin{tabular}{|c|c|c|c|c|c|c|c|c|c|}
\hline General characteristics & & & & & & & & & \\
\hline Region & & & & & & & & & \\
\hline Lake Geneva region & Dummy $=1$, if region Lake Geneva & $\begin{array}{c}0.1699 \\
(0.3756)\end{array}$ & $\begin{array}{c}0.1785 \\
(0.3830)\end{array}$ & $\begin{array}{c}0.1849 \\
(0.3882)\end{array}$ & $\begin{array}{c}0.1696 \\
(0.3753)\end{array}$ & $\begin{array}{c}0.1847 \\
(0.3881)\end{array}$ & $\begin{array}{c}0.1672 \\
(0.3732)\end{array}$ & $\begin{array}{c}0.1971 \\
(0.3978)\end{array}$ & $\begin{array}{c}0.1672 \\
(0.3732)\end{array}$ \\
\hline Espace Mittelland & Dummy = 1 , if region Espace Mittelland & $\begin{array}{c}0.2141 \\
(0.4102)\end{array}$ & $\begin{array}{c}0.2108 \\
(0.4079)\end{array}$ & $\begin{array}{c}0.2170 \\
(0.4122)\end{array}$ & $\begin{array}{c}0.2071 \\
(0.4053) \\
\end{array}$ & $\begin{array}{c}0.2145 \\
(0.4105) \\
\end{array}$ & $\begin{array}{c}0.2082 \\
(0.4061) \\
\end{array}$ & $\begin{array}{c}0.2148 \\
(0.4108)\end{array}$ & $\begin{array}{r}0.2082 \\
(0.4061) \\
\end{array}$ \\
\hline Northwestern Switzerland & Dummy $=1$, if region Northwestern Switzerland & $\begin{array}{c}0.1236 \\
(0.3292) \\
\end{array}$ & $\begin{array}{c}0.1437 \\
(0.3508) \\
\end{array}$ & $\begin{array}{c}0.1295 \\
(0.3358) \\
\end{array}$ & $\begin{array}{c}0.1465 \\
(0.3536) \\
\end{array}$ & $\begin{array}{c}0.1288 \\
(0.3350) \\
\end{array}$ & $\begin{array}{c}0.1501 \\
(0.3572) \\
\end{array}$ & $\begin{array}{c}0.1332 \\
(0.3389) \\
\end{array}$ & $\begin{array}{c}0.1501 \\
(0.3572) \\
\end{array}$ \\
\hline Eastern Switzerland & Dummy $=1$, if region Eastern Switzerland & $\begin{array}{c}0.1298 \\
(0.3361)\end{array}$ & $\begin{array}{c}0.1133 \\
(0.3170)\end{array}$ & $\begin{array}{c}0.1186 \\
(0.3233)\end{array}$ & $\begin{array}{c}0.1163 \\
(0.3206)\end{array}$ & $\begin{array}{c}0.1182 \\
(0.3228)\end{array}$ & $\begin{array}{c}0.1163 \\
(0.3206)\end{array}$ & $\begin{array}{c}0.1084 \\
(0.3110)\end{array}$ & $\begin{array}{c}0.1163 \\
(0.3206)\end{array}$ \\
\hline Central Switzerland & Dummy $=1$, if region Central Switzerland & $\begin{array}{c}0.1153 \\
(0.3195)\end{array}$ & $\begin{array}{c}0.1112 \\
(0.3144)\end{array}$ & $\begin{array}{c}0.1142 \\
(0.3181)\end{array}$ & $\begin{array}{c}0.1105 \\
(0.3135) \\
\end{array}$ & $\begin{array}{r}0.1137 \\
(0.3174) \\
\end{array}$ & $\begin{array}{c}0.1105 \\
(0.3135) \\
\end{array}$ & $\begin{array}{c}0.1123 \\
(0.3157)\end{array}$ & $\begin{array}{r}0.1105 \\
(0.3135) \\
\end{array}$ \\
\hline Zurich & Dummy = 1 , if region Zurich (Reference) & $\begin{array}{c}0.1713 \\
(0.3768)\end{array}$ & $\begin{array}{c}0.1800 \\
(0.3842)\end{array}$ & $\begin{array}{c}0.1525 \\
(0.3595)\end{array}$ & $\begin{array}{c}0.1987 \\
(0.3990)\end{array}$ & $\begin{array}{c}0.1591 \\
(0.3658)\end{array}$ & $\begin{array}{c}0.1991 \\
(0.3993)\end{array}$ & $\begin{array}{c}0.1490 \\
(0.3561)\end{array}$ & $\begin{array}{r}0.1991 \\
(0.3993) \\
\end{array}$ \\
\hline Ticino & Dummy $=1$, if region Ticino & $\begin{array}{c}0.0760 \\
(0.2650)\end{array}$ & $\begin{array}{c}0.0625 \\
(0.2421) \\
\end{array}$ & $\begin{array}{c}0.0833 \\
(0.2764) \\
\end{array}$ & $\begin{array}{c}0.0514 \\
(0.2208) \\
\end{array}$ & $\begin{array}{c}0.0810 \\
(0.2729) \\
\end{array}$ & $\begin{array}{c}0.0485 \\
(0.2149) \\
\end{array}$ & $\begin{array}{c}0.0853 \\
(0.2793) \\
\end{array}$ & $\begin{array}{r}0.0485 \\
(0.2149) \\
\end{array}$ \\
\hline Yearly dummies & & & & & & & & & \\
\hline 1999 & & $\begin{array}{c}0.0856 \\
(0.2799)\end{array}$ & $\begin{array}{c}0.0859 \\
(0.2802)\end{array}$ & $\begin{array}{c}0.0847 \\
(0.2785)\end{array}$ & $\begin{array}{c}0.0867 \\
(0.2814) \\
\end{array}$ & $\begin{array}{c}0.0838 \\
(0.2772) \\
\end{array}$ & $\begin{array}{c}0.0880 \\
(0.2834) \\
\end{array}$ & $\begin{array}{c}0.0823 \\
(0.2749)\end{array}$ & $\begin{array}{r}0.0880 \\
(0.2834) \\
\end{array}$ \\
\hline 2000 & (Reference) & $\begin{array}{c}0.0827 \\
(0.2754) \\
\end{array}$ & $\begin{array}{c}0.0859 \\
(0.2802) \\
\end{array}$ & $\begin{array}{c}0.0819 \\
(0.2742) \\
\end{array}$ & $\begin{array}{c}0.0877 \\
(0.2829) \\
\end{array}$ & $\begin{array}{c}0.0820 \\
(0.2744) \\
\end{array}$ & $\begin{array}{c}0.0886 \\
(0.2842) \\
\end{array}$ & $\begin{array}{c}0.0814 \\
(0.2735) \\
\end{array}$ & $\begin{array}{c}0.0886 \\
(0.2842) \\
\end{array}$ \\
\hline 2001 & & $\begin{array}{c}0.0907 \\
(0.2872)\end{array}$ & $\begin{array}{c}0.0940 \\
(0.2919)\end{array}$ & $\begin{array}{c}0.0937 \\
(0.2914)\end{array}$ & $\begin{array}{c}0.0928 \\
(0.2902) \\
\end{array}$ & $\begin{array}{c}0.0919 \\
(0.2889) \\
\end{array}$ & $\begin{array}{c}0.0947 \\
(0.2928) \\
\end{array}$ & $\begin{array}{c}0.0929 \\
(0.2903)\end{array}$ & $\begin{array}{c}0.0947 \\
(0.2928)\end{array}$ \\
\hline 2002 & & $\begin{array}{c}0.2010 \\
(0.4008)\end{array}$ & $\begin{array}{c}0.1942 \\
(0.3956)\end{array}$ & $\begin{array}{c}0.2037 \\
(0.4028)\end{array}$ & $\begin{array}{c}0.1893 \\
(0.3918)\end{array}$ & $\begin{array}{c}0.2034 \\
(0.4025)\end{array}$ & $\begin{array}{c}0.1873 \\
(0.3902)\end{array}$ & $\begin{array}{c}0.2054 \\
(0.4040)\end{array}$ & $\begin{array}{c}0.1873 \\
(0.3902)\end{array}$ \\
\hline 2003 & & $\begin{array}{c}0.2117 \\
(0.4085)\end{array}$ & $\begin{array}{c}0.1969 \\
(0.3977)\end{array}$ & $\begin{array}{c}0.2050 \\
(0.40385)\end{array}$ & $\begin{array}{c}0.1968 \\
(0.3976)\end{array}$ & $\begin{array}{c}0.2073 \\
(0.4054)\end{array}$ & $\begin{array}{c}0.1928 \\
(0.3946)\end{array}$ & $\begin{array}{c}0.2036 \\
(0.4027)\end{array}$ & $\begin{array}{c}0.1928 \\
(0.3956)\end{array}$ \\
\hline 2004 & & $\begin{array}{c}0.1742 \\
(0.3793)\end{array}$ & $\begin{array}{c}0.1784 \\
(0.3829)\end{array}$ & $\begin{array}{c}0.1753 \\
(0.3802)\end{array}$ & $\begin{array}{c}0.1792 \\
(0.3835) \\
\end{array}$ & $\begin{array}{c}0.1764 \\
(0.3812) \\
\end{array}$ & $\begin{array}{c}0.1786 \\
(0.3830) \\
\end{array}$ & $\begin{array}{c}0.1781 \\
(0.3827)\end{array}$ & $\begin{array}{c}0.1786 \\
(0.3830)\end{array}$ \\
\hline 2005 & & $\begin{array}{c}0.1541 \\
(0.3611)\end{array}$ & $\begin{array}{c}0.1657 \\
(0.3709)\end{array}$ & $\begin{array}{c}0.1557 \\
(0.3626)\end{array}$ & $\begin{array}{c}0.1674 \\
(0.3734)\end{array}$ & $\begin{array}{c}0.1552 \\
(0.3621)\end{array}$ & $\begin{array}{c}0.1700 \\
(0.3456)\end{array}$ & $\begin{array}{c}0.1561 \\
(0.3630)\end{array}$ & $\begin{array}{c}0.1700 \\
(0.3756)\end{array}$ \\
\hline
\end{tabular}


Table A2: Entrepreneur - Margins estimation with control variables

\begin{tabular}{|c|c|c|c|c|c|c|c|c|}
\hline \multirow[b]{3}{*}{ Variables } & \multicolumn{7}{|c|}{ Dependent variable: Entrepreneur } & \\
\hline & \multicolumn{2}{|c|}{ Type 1: Ownership structure } & \multicolumn{2}{|c|}{ Type 2: Lazear definition } & \multicolumn{2}{|c|}{$\begin{array}{l}\text { Type 3: Lazear definition } \\
\text { applied to } \mathrm{CH}\end{array}$} & \multicolumn{2}{|c|}{ Type 4: Management position } \\
\hline & Coeff & $\begin{array}{l}\text { P-Value } \\
\text { - }\end{array}$ & Coeff & P-Value & Coeff & P-Value & Coeff & P-Value \\
\hline voc & 0.000 & Ref. & 0.000 & Ref. & 0.000 & Ref. & 0.000 & Ref. \\
\hline voc+vod & -0.036 & $0.025 * *$ & 0.018 & 0.307 & -0.006 & 0.741 & 0.018 & 0.360 \\
\hline acad & -0.018 & 0.217 & 0.024 & 0.109 & 0.006 & 0.684 & 0.023 & 0.174 \\
\hline acad+acad & 0.150 & $0.000 * * *$ & 0.157 & $0.000 * * *$ & 0.138 & $0.000^{* * * *}$ & 0.081 & $0.002 * * *$ \\
\hline M_acad+voc & 0.009 & 0.676 & -0.027 & 0.245 & -0.002 & 0.927 & -0.009 & 0.720 \\
\hline M_acad+acad+voc & 0.083 & $0.036 * *$ & 0.075 & $0.047 * *$ & 0.094 & $0.011^{* *}$ & 0.071 & $0.094 * *$ \\
\hline M_voctacad & 0.018 & 0.753 & 0.160 & $0.002^{* * * *}$ & 0.124 & $0.014 * *$ & 0.156 & $0.012 * *$ \\
\hline M_voc+voctacad & 0.024 & 0.497 & 0.056 & 0.136 & 0.078 & $0.036^{* * *}$ & 0.086 & $0.039 * *$ \\
\hline Work exp. (per 10 yrs) & 0.106 & $0.000^{* * * *}$ & 0.210 & $0.000 * * *$ & 0.201 & $0.000^{* * * *}$ & 0.184 & $0.000^{* * * *}$ \\
\hline Work exp. Sq (per 10 yrs) & -0.013 & $0.000^{* * * *}$ & -0.033 & $0.000 * * *$ & -0.029 & $0.000 * * *$ & -0.027 & $0.000^{* * * *}$ \\
\hline Men & 0.015 & 0.282 & 0.078 & $0.000 * * *$ & 0.067 & $0.000^{* * * *}$ & 0.073 & $0.000^{* * * *}$ \\
\hline Children & 0.010 & 0.455 & 0.047 & $0.001 * * *$ & 0.037 & $0.009 * * *$ & 0.042 & $0.010 * * *$ \\
\hline Married & 0.000 & Ref. & 0.000 & Ref. & 0.000 & Ref. & 0.000 & Ref. \\
\hline Single & -0.062 & $0.000^{* * *}$ & -0.087 & $0.000 * * *$ & -0.085 & $0.000 * * *$ & -0.058 & $0.001 * * *$ \\
\hline Divorced & 0.022 & 0.238 & -0.046 & $0.013^{* *}$ & 0.005 & 0.797 & -0.013 & 0.564 \\
\hline \multirow[t]{5}{*}{ Widowed } & -0.059 & 0.179 & -0.111 & $0.042^{* * *}$ & -0.131 & $0.032^{* *}$ & -0.119 & $0.043 * *$ \\
\hline & $\mathrm{N}$ & 15395 & $\mathrm{~N}$ & 15395 & $\mathrm{~N}$ & 15395 & $\mathrm{~N}$ & 11658 \\
\hline & Wald chi2 & 326.12 & Wald chi2 & 712.18 & Wald chi2 & 736.86 & Wald chi2 & 473.44 \\
\hline & Prob $>$ chi2 & $0.000 * * *$ & Prob $>$ chi2 & $0.000 * * * *$ & Prob $>$ chi2 & $0.000^{* * * *}$ & Prob $>$ chi2 2 & $0.000 * * *$ \\
\hline & Pseudo R2 & 0.042 & Pseudo R2 & 0.064 & Pseudo R2 & 0.066 & Pseudo R2 & 0.056 \\
\hline
\end{tabular}

Region and survey year controls are included

Regressions are estimated with cluster-robust standard errors

The coefficients show marginal effects calculated for each person in the data and then averaged

$* * *$ significant on $1 \%, * *$ on $5 \%, *$ on $10 \%$ level

Source: own estimations based on Swiss Labor Force Survey, FSO 


\begin{tabular}{lll}
\hline & \multicolumn{2}{l}{ Dependent variable: Matura degree } \\
\hline Variables & Coeff & P-Value \\
Matura quote & 0.007 & $0.000^{* * *}$ \\
\hline & \\
\hline & $\mathrm{N}$ & 15445 \\
& Wald chi2 & 518.91 \\
& Prob > chi2 & $0.000^{* * *}$ \\
& Pseudo R2 & 0.058 \\
\hline
\end{tabular}

Controls for gender and survey years are included

Regressions are estimated with cluster-robust standard errors

The coefficients show marginal effects calculated for each person in the data and then averaged

$* * *$ significant on $1 \%, * *$ on $5 \%, *$ on $10 \%$ level

\section{Appendix B}

\section{The Swiss system of education and qualifications}

The educational system of Switzerland is very diverse as each canton has its own schooling system and only part of it is regulated by the central government.

\section{Compulsory education}

Depending on the canton, children normally enter the primary level of education (ISCED 1) at the age of 6 or 7 . The duration varies from canton to canton, ranging from four to six years. Primary education is then followed by the lower secondary level of education (ISCED 2). From this level on, children in Switzerland get educated according to their potential and skills. This leads to two to four different performance levels at the lower secondary level of education. Compulsory education is completed after the lower secondary education, adding up to nine mandatory school years all over Switzerland.

\section{Upper secondary education}

Thus, the upper secondary education level normally starts at the age of 15 or 16 , when teenagers in Switzerland can choose between two different types of education. One can either follow the vocational path and complete an apprenticeship (ISCED 
3B) or, after taking an admission test, continue on the academic education path (ISCED 3A) and obtain a university admission certificate (Matura). In Switzerland, an apprenticeship normally takes between two and four years and typically combines on-the-job training in a firm (between three and four days a week) with a theoretical education (between one and two days a week). This so-called «dual-system of vocational education» is very popular in Switzerland: two-thirds of the teenagers choose to do an apprenticeship, while only about one-fifth get a Matura degree (FSO, 2008b).

\section{Tertiary education}

A successfully completed upper secondary education is required to continue on the tertiary level. Here, too, one can choose between academic and vocational education. As for the higher academic education, there are universities and Federal Institutes of Technology (ISCED 5A) with unrestricted access to those who obtain a Matura degree. These institutions then confer academic degrees, which can be further followed by a doctorate program. People on the vocational path, on the other hand, have the option of following a tertiary education by attending a higher vocational school or a University of Applied Sciences (ISCED 5A and 5B).

\section{References}

Ahmad, N.\& Seymour, R.G. (2008). Defining Entrepreneurial Activity: Definitions Supporting Frameworks for Data Collection. OECD Statistics Working Paper Series. Available at SSRN: http://ssrn. com/abstract $=1090372$

Astebro, T. (2006). Does it pay to be a jack-of-all-trades? (August 2006). Available at SSRN: http://ssrn. com/abstract $=925221$

Astebro, T. \& Thompson, P. (2007). Entrepreneurs: Jacks of all Trades or Hobos? (May 2007). Available at SSRN: http://ssrn.com/abstract=925221

Backes-Gellner, U.\& Moog, P. (2008). Who Chooses to Become an Entrepreneur? The Jacks-of-AllTrades in Social and Human Capital. (February 2008). Available at SSRN: http://ssrn.com/abstract $=109108$

Baumol, W.J. (2004). Education for Innovation: Entrepreneurial Breakthroughs vs. Corporate Incremental Improvements. NBER Working Paper Series, No. 10578

Davidsson, P. \& Honig, B. (2003). The role of social and human capital among nascent entrepreneurs. Journal of Business Venturing, 18, 301-331

Federal Statistical Office (FSO) (2004). Die Swiss Labor Force Survey (SLFS). Konzepte - Methodische Grundlagen - Praktische Ausführungen. Neuenburg: Federal Statistical Office

Federal Statistical Office (FSO) (2008a). «Erhebungen, Sourcen - Swiss Labor Force Survey (SLFS)» http://www.bfs.admin.ch/bfs/portal/de/index/infothek/erhebungen__Sourcen/blank/blank/enquete_ suisse_sur/uebersicht.html, 05.04.2008

Federal Statistical Office (FSO) (2008b). «Klassifikation der schweizerischen Bildunsstatistik» http:// www.portal-stat.admin.ch/isced97/files/do-d-15.02-isced-02.pdf, 06.07.2010

Honig, B. (1996). Education and Self-Employment in Jamaica. Comparative Education Review, 40(2), $177-193$

Lazear, E.P. (2004). Balanced Skills and Entrepreneurship. The American Economic Review, 94(2), 208211 
Lazear, E.P. (2005). Entrepreneurship. Journal of Labor Economics, 23(4), 649-680

Robinson, P.B. \& Sexton, E.A. (1994). The Effect of Education and Experience on Self-Employment Success. Journal of Business Venturing, 9, 141-156

Silva, O. (2007). The Jack-of-All-Trades entrepreneur: Innate talent or acquired skill? Economics Letters, 97, 118-123

Tuor, S.\& Backes-Gellner, U. (2010). Risk-Return Trade-Offs to Different Educational Paths: Vocational, Academic and Mixed. International Journal of Manpower, forthcoming

Wagner, J. (2003). Testing Lazear's Jack-of-All-Trades View of Entrepreneurship with German Micro Data. Applied Economics Letters, 10(11), 687-689

Wagner, J. (2006). Are Nascent Entrepreneurs Jack-of-All-Trades? A Test of Lazear's Theory of Entrepreneurship with German Data. Applied Economics Letters, 38(20), 2415-2419

Wooldridge, J.M. (2002). Econometric Analysis of Cross Section and Panel Data. Cambridge, Ma.: MIT Press 